\title{
ANALISIS FINANCIAL DISTRESS DENGAN ACCOUNTING RATIO DAN FORECASTING BANKRUPCY TERHADAP PERUSAHAAN PERBANKAN GO PUBLIC DI INDONESIA
}

\author{
Rihardhiny Nariswari Putri \\ e-mail: dhinynariswari@gmail.com \\ Djuminah \\ Fakultas Ekonomi dan Bisnis Universitas Sebelas Maret
}

\begin{abstract}
This study aims to analyze the prediction level of bankruptcy by the method of Altman Z Score on banking companies Go Public during the year 2010-2014, the prediction of performance by using intellectual capital in companies that Go Public during the year 2010-2014 and the influence between intellectual capital against the risk of bankruptcy on Go Public companies are battling for 2010-2014.

This research uses quantitative method to know its direct effect. Meanwhile, to analyze the risk of bankruptcy using Altman Z-Score and to analyze intellectual capital using VAIC.The results of this study are a) During 2010 - 2014 the average banking indicated bankrupt $43.45 \%, 50.34 \%$ gray, and not bankrupt $6.21 \%$. B) The average value of intellectual capital in 2010 2014 with the top category of $24.14 \%$, good as much as $38.62 \%$, common as much as $28.28 \%$ and bad as much as $8.97 \%$. Thus it can be said that intellectual capital of banking in Indonesia is relatively good to support company performance. C) There is a significant negative influence between intellectual capital against bankruptcy risk.
\end{abstract}

Keywords: Bankruptcy, Intellectual Capital

\begin{abstract}
ABSTRAK
Penelitian ini bertujuan untuk menganalisis prediksi tingkat kebangkrutan dengan metode Altman Z Score pada perusahaan perbankan yang Go Public selama tahun 2010-2014, prediksi performa dengan menggunakan intellectual capital pada perusahaan yang Go Public selama tahun 2010-2014 dan pengaruh antara intellectual capital terhadap resiko kebangkrutan pada perusahaan Go Public perbangkan selama tahun 20102014.

Penelitian ini menggunakan metode kuantitatif untuk mengetahui pengaruh langsungnya.Sementara itu, untuk menganalisis resiko kebangkrutan menggunakan Altman Z-Score dan untuk menganalisis intellectual capital menggunakan VAIC.

Hasil Penelitian ini adalah a) Selamatahun 2010 - 2014 rata-rata perbankan yang terindikasi bangkrut $43,45 \%$, abu-abu $50,34 \%$, dan tidak bangkrut $6,21 \%$. b) Nilai rata-rata intellectual capital pada tahun 2010-2014 dengan kategori top sebanyak $24,14 \%$, good sebanyak $38,62 \%$, common sebanyak $28,28 \%$ dan bad sebanyak 8,97\%. Dengan demikian dapat
\end{abstract}


dikatakan bahwa intellectual capital perbankan di Indonesia relatif baik untuk mendukung kinerja perusahaan. c) Terdapat pengaruh negative yang signifikan antara intellectual capital terhadap resiko kebangkrutan.

Kata Kunci: Kebangkrutan, Intellectual Capital

Penelitian ini didasari oleh kondisi ekternal yang penuh ketidakpastian. Kondisi ekonomi global dari tahun 2008 sampai 2014 mengalami ketidakstabilan, hal ini ditandai dengan adanya krisis amerika dan eropa serta nilai mata uang dollar yang terus menguat. Ditambahkan juga Amerika Serikat menghentikan program Quantitative Easing (QE) yang menyebabkan uang yang beredar semakin berkurang. Kondisi tersebut sedikit banyak berpengaruh terhadap ekonomi makro Indonesia karena masuk dalam kategori emerging market. Sementara itu secara ekonomi makro laju inflasi tidak stabil dan cenderung meningkat dari tahun ke tahun selama periode tahun 2008 - 2014. Dengan adanya kondisi tersebut, dinamisme perusahaan perbankan rata-rata akan berpengaruh. Dengan mengetahui kondisi eksternal seperti di atas, penelitian difokuskan untuk mengkaji resiko kebangkrutan jika dilihat dari sisi internal. Karena perusahaan yang baik adalah perusahaan yang mampu bertahan dari ketidakpastian eksternal dengan menguatkan manajemen internalnya.

Secara teori, penelitian ini menggabungkan beberapa penelitian terkait dengan intellectual capital dan kebangkrutan serta melihat pengaruhnya secara langsung. Berdasarkan penelitiannya a) Mollabashi (2014) dalam penelitiannya menjelaskan bahwa intellectual capital berpengaruh negative terhadap resiko kebangkrutan, b) Ulum (2014) menjelaskan bahwa intellectual capital melalui menggunaan M-VAIC mampu mendeteksi tingkat kesehatan perusahaan perbankan, c) Altman (1968) membuat suatu terobosan dalam model prediksi kebangkrutan. Altman memilih untuk meninggalkan pencarian rasio tunggal terbaik sebagai pengukur prediksi kebangkrutan dan memutuskan untuk membuat model statistik yang komprehensif menggunakan teknik MDA. MDA memudahkan peneliti untuk menggolongkan observasinya ke dalam beberapa kategori.

Ketika Altman menambahkan kelima rasio tersebut secara proporsional dengan proporsi yang didapat dari prosedur analisis diskriminan multivariat (MDA), didapatkan suatu ukuran yang sangat tepat yang kemudian dinamakan Nilai Z. Model ini memiliki akurasi 94 persen untuk perusahaan bangkrut dan 97 persen untuk perusahaan tidak bangkrut untuk periode satu tahun sebelum perusahaan bermasalah mengajukan permohonan kebangkrutan. Peneliti tertarik untuk mengkombinasikan ketiga penelitian yang relevan tersebut menjadi satu model penelitian untuk mengetahui nilai tingkat intellectual capital dan resiko kebangkrutan serta menganalisis pengaruhnya. Sehingga hasil penelitian ini diharapkan akan dapat memberikan pemahaman yang mendalam tentang kinerja perusahaan jika dilihat dari resiko kebangkrutan dan intellectual capital.

Tujuan pada penelitian ini adalah sebagai berikut:

1. Menganalisis prediksi tingkat kebangkrutan dengan metode Altman Z Score pada perusahaan perbankan yang Go Public selama tahun 2010-2014.

2. Menganalisis prediksi performa dengan menggunakan intellectual capital pada perusahaan yang Go Public selama tahun 2010-2014

3. Menganalisis pengaruh antara intellectual capital terhadap resiko kebangkrutan pada perusahaan Go Public perbangkan selama tahun 2010-2014. 


\section{TELAAH PUSTAKA}

\section{Bank}

Undang-Undang Republik Indonesia No. 10 Tahun 1998 tentang "Perbankan" (Ade Arthesa dan Edia Handiman, 2006:6) menyebutkan bank adalah badan usaha yang menghimpun dana dari masyarakat dalam bentuk simpanan dan menyalurkannya kepada masyarakat dalam bentuk kredit dan/atau bentuk-bentuk lainnya dalam rangka meningkatkan taraf hidup rakyat banyak. Dari pengertian di atas dapat dijelaskan secara lebih luas bahwa bank merupakan perusahaan yang bergerak dalam bidang keuangan, artinya aktivitas perbankan selalu berkaitan dalam bidang keuangan. (Kasmir, 2008 : 25-26).

\section{Laporan Keuangan}

Brigham (2001:38) Diantara berbagai laporan yang diterbitkan perusahaan kepada pemegang saham, laporan tahunan (annual report) adalah laporan yang paling penting. Ada dua jenis informasi yang diberikan dalam laporan ini. Pertama, adalah bagian verbal, yang sering kali disajikan sebagai surat dari presiden direktur yang menguraikan hasil operasi perusahaan selama tahun lalu dan membahas perkembangan baru yang akan mempengaruhi operasi perusahaan di masa depan. Kedua, laporan tahunan yang menyajikan empat laporan keuangan dasar neraca, laporan laba - rugi, laporan laba ditahan, dan laporan arus kas. Laporan - Iaporan tersebut menyajikan angka - angka akuntansi dari operasi dan posisi keuangan perusahaan. Analisis laporan keuangan adalah seni untuk mengubah data dari laporan keuangan menjadi informasi yang berguna bagi pengambilan keputusan (Van Horne $\&$ Wachowicz, 2005:193).

\section{Resiko Kebangkrutan}

Financial distress atau kesulitan keuangan dapat diartikan sebagai ketidakmampuan perusahaan untuk membayar kewajiban keuangannya pada saat jatuh tempo yang menyebabkan kebangkrutan perusahaan (Darsono dan Ashari, 2005). Atmini (2005) mendefinisikan financial distress jika melakukan pemberhentian tenaga kerja atau menghilangkan pembayaran dividen. Perusahaan mengalami financial distress jika perusahaan menghentikan operasinya dan perusahaan mengalami pelanggaran teknis dalam hutang dan diprediksi akan mengalami kebangkrutan pada periode yang akan datang.

\section{Metode Analisis Resiko Kebangkrutan dengan Menggunakan Z-Score}

Analisis diskriminan dilakukan untuk memprediksi kebangkrutan suatu perusahaan dengan menganalisis laporan keuangan perusahaan dua sampai lima tahun sebelum perusahaan tersebut diprediksi bangkrut. Kebangkrutan adalah suatu kondisi disaat perusahaan mengalami ketidakcukupan dana untuk menjalankan usahanya. Kebangkrutan biasanya dihubungkan dengan kesulitan keuangan. Analisis diskriminan bermanfaat bagi perusahaan untuk memperoleh peringatan awal kebangkrutan dan kelanjutan usahanya. Semakin awal suatu perusahaan memperoleh peringatan kebangkrutan, semakin baik bagi pihak manajemen karena pihak manajemen bisa melakukan perbaikan-perbaikan dan dapat memberikan gambaran dan harapan yang mantap terhadap nilai masa depan perusahaan tersebut.

\section{Intellectual Capital}

Stewart (1997) dalam Rehman et al. (2011) mendefinisikan intellectual capital sebagai suatu pengetahuan dan informasi yang menciptakan efisiensi value added untuk menghasilkan kekayaan perusahaan. Pulic (2001) dalamRehman et al. (2011) menyimpulkan intellectual capital sebagai kemampuanpegawai untuk menciptakan efisiensi value added. 
Jadi Modal Intelektual yang dimaksud dalam penelitian ini adalah modal intelektual yang diukur berdasarkan pengukuran dari model value added yang diproksikan dari physical capital, human capital dan structural capital, seperti yang sudah dijelaskan sebelumnya bahwa penjumlahan dari ketiganya dikenal dengan VAICTM. Menurut Ulum (2009), pengukuran value added dari modal intellektual formulanya adalah sebagai berikut;

$$
\text { VAICTM = VACA + VAHU + STVA }
$$

Performa M-VAIC diklasifikasikan menjadi 4 kategori yaitu:

1. Top performers $¥$ M-VAIC score of above 3.50

2. Good performers $¥$ M-VAIC score of between 2.5 and 3.49

3. Common performers $¥ \mathrm{M}-\mathrm{VAIC}$ score of between 1.5 and 2.4

4. Bad performers $¥$ M-VAIC score of below 1.5.

\section{Kerangka Berpikir}

Terdapat tiga tahap dalam penelitian ini yaitu:menganalisis prediksi kesehatan perusahaan perbankan dengan variabel intellectual capital melalui model VAIC,menganalisis tingkat kebangkrutan dengan menggunakan model Altman Zscore, menganalisis pengaruh antara intellectual capital dengan resiko kebangkrutan. berikut merupakan diagram kerangka berpikirnya yang ditunjukkan pada gambar 1 .

\begin{tabular}{|c|c|}
\hline & Risk Bangkrupty \\
\hline Intellectual Capital & $\mathrm{X} 1=\mathrm{WC} / \mathrm{TA}$ \\
\hline$V A C A$ & $\mathrm{X} 2=\mathrm{RE} / \mathrm{TA}$ \\
\hline$V A H U$ & $\mathrm{X} 3$ = EBIT/TA \\
\hline STVA & $\begin{array}{l}\mathrm{X} 4=\mathrm{MVE} / \mathrm{BV} \\
\mathrm{X} 5=\mathrm{S} / \mathrm{TA}\end{array}$ \\
\hline
\end{tabular}

Gambar 1. Kerangka Berpikir

Sumber: Bryan (2013) dan Zaabi (2011)

\section{Perumusan Hipotesis}

Berdasarkan penelitian yang relevan maka dapat dirumuskan hipotesis sebagai berikut:

H1: diduga metode Altman Z score dapat mengklasifikasikan perbankan terhadap resiko kebangkrutan.

H2: di duga model VAIC dapat mengklasifikasikan tingkat kesehatan perbankan yang Go Publik

$\mathrm{H} 2$ : terdapat pengaruh negative antara intellectual capital pada resiko kebangkrutan.

\section{METODE PENELITIAN}

\section{Definisi Operasional dan Pengukuran Variabel}

1. Resiko Kebangkrutan

Kebangkrutan adalah puncak dari kegagalan dalam mengelola suatu usaha. Kegagalan tersebut dapat berupa kegagalan dalam mengelola modal kerja yang terdapat di perusahaan atau kegagalan dalam bertahan dalam persaingan yang semakin tidak menentu. Brigham dan Gapenski (2008). Pada penelitian ini menggunakan model Altman Z-score untuk mengetahui tingkat kebangkrutan. Altman (1968) menggunakan persamaan untuk menentukan nilai tingkat kebangkrutan dengan rumus $\mathrm{Z}=0.012 \times 1+0.014 \times 2+0.033 \times 3+0.006 \mathrm{X} 4+$ $0.999 \times 5$, dimana $X 1=$ working capital $/$ total assets, $X 2=$ retained earnings/total 
assets, $\mathrm{X} 3=$ earnings before interest and taxes/total assets, $\mathrm{X} 4=$ market value of equity/book value of total liabilities dan X5 = sales/total assets.

2. Intellectual Capital

Stewart (1997) dalam Rehman et al. (2011) mendefinisikan intellectual capital sebagai suatu pengetahuan dan informasi yang menciptakan efisiensi value added untuk menghasilkan kekayaan perusahaan. Pulic (2001) dalamRehman et al. (2011) menyimpulkan intellectual capital sebagai kemampuanpegawai untuk menciptakan efisiensi value added. Penelitian ini mengacu pada penelitian Pulic (1997) dengan menggunakan 3 indikator yaitu Physical Capital, Human Capital, dan Structural Capital (SC). Jadi Modal Intelektual yang dimaksud dalam penelitian ini adalah modal intelektual yang diukur berdasarkan pengukuran dari model value added yang diproksikan dari physical capital, human capital dan structural capital, seperti yang sudah dijelaskan sebelumnya bahwa penjumlahan dari ketiganya dikenal dengan VAICTM. pengukuran value added dari modal intellektual formulanya adalah sebagai berikut: VAICTM $=$ VACA + VAHU + STVA

\section{Teknik Analisis Data}

1. Metode Altman Z Score

Pada tahun 1968 Edward I. Altman membuat suatu terobosan dalam model prediksi kebangkrutan. Altman memilih untuk meninggalkan pencarian rasio tunggal terbaik sebagai pengukur prediksi kebangkrutan dan memutuskan untuk membuat model statistik yang komprehensif menggunakan teknik MDA. MDA memudahkan peneliti untuk menggolongkan observasinya ke dalam beberapa kategori. Kategori yang digunakan Altman dalam penelitiannya adalah perusahaan bangkrut dan non bangkrut. Ketika Altman menambahkan kelima rasio tersebut secara proporsional dengan proporsi yang didapat dari prosedur analisis diskriminan multivariat (MDA), ia mendapatkan suatu ukuran yang sangat tepat yang kemudian dinamakan Nilai $Z$.

Altman (1968) Rumus persamaannya adalah:

Dimana:

$X 1=$ working capital/total assets,

$\mathrm{X} 2$ = retained earnings/total assets,

$\mathrm{X} 3$ = earnings before interest and taxes/total assets,

$X 4=$ market value of equity/book value of total liabilities

$\mathrm{X} 5=$ sales/total assets.

$$
Z=0.012 \times 1+0.014 \times 2+0.033 \times 3+0.006 \times 4+0.999 \times 5
$$

2. Value Added Intellectual Coefficient (VAIC)

Sebuah perusahaan dapat mengetahui penilaian pasar dengan menggunakan metode pengukuran Value Added Intellectual Capital (VAIC ${ }^{\mathrm{TM}}$ ), yaitu dengan melihat kemampuan intelektual yang dimiliki oleh perusahaan tersebut dan nilai yang dimiliki perusahaan tersebut. Komponen utama dari VAICTM yang dikembangkan Pulic tersebut dapat dilihat dari sumber daya perusahaan, yaitu physical capital (VACA - Value Added Capital Employed), human capital (VAHU - Value Added Human Capital), dan structural capital (STVA Structural Capital Value Added).

VAHU mengindikasikan berapa banyak Value Added (VA) dapat dihasilkan dengan dana yang dikeluarkan untuk tenaga kerja pegawai (Tan et al., 2007:79 dalam Ulum 2008). Human capital merepresentasikan kemampuan perusahaan dalam mengelola modal pengetahuan individu organisasi yang dipresentasikan oleh karyawannya sebagai aset strategic perusahaan karena pengetahuan yang 
mereka miliki. Hubungan antara VA dengan HC mengindikasikan HC untuk menciptakan nilai di dalam perusahaan.

Dalam model yang dikembangkan Pulic ini, STVA dihitung dengan membagi structural capital (SC) dengan value added (VA). Dalam model Pulic, SC diperoleh dari VA dikurangi dengan HC. STVA menunjukkan kontribusi modal struktural dalam penciptaan nilai semakin kecil kontribusi HC dalam penciptaan nilai maka akan semakin besar kontribusi SC (Tan et al., 2007:80 dalam Ulum, 2008).

VACA adalah indikator untuk value added yang diciptakan oleh satu unit dari physical capital terhadap value added perusahaan. VACA adalah perbandingan antara value added (VA) dengan model fisik yang bekerja (CA). Dalam proses penciptaan nilai, intelektual potensial yang direpresentasikan dalam biaya karyawan tidak dihitung sebagai biaya (input).

$$
\text { VAICTM }=\text { VACA + VAHU + STVA }
$$

Hasilkalkulasi berdasarkan kinerjaM-VAIC dan diklasifikasikanmenjadi empatkategorisebagai berikut:

a. Top performers - M-VAIC skor di atas 3.50

b. Good performers-M-VAIC skor antara 2.5 sampai 3.49

c. Common performers -M-VAIC skor antara 1.5 sampai 2.49

d. Bad performers-M-VAIC skor di bawah 1.5.

\section{HASI L DAN PEMBAHASAN}

\section{Analisis Resiko Kebangkrutan Dengan Altman Z Score}

Berdasarkan penelitian Altman (1997) tersebut, maka pada penelitian akan dianalisis resiko kebangkrutan perusahaan perbankan yang go public dengan menggunakan persamaan $4 \mathrm{X}$. adapun analisis datanya sebagai berikut:

a. Altman Z Score Tahun 2010

Analisis data dengan menggunakan Altman Z Score pada tahun 2010 ini melibatkan 29 bank yang go public dan Iaporan keuangannya dirilis Bursa Efek Ind onesia dalam websitenya www.idx.go.id.

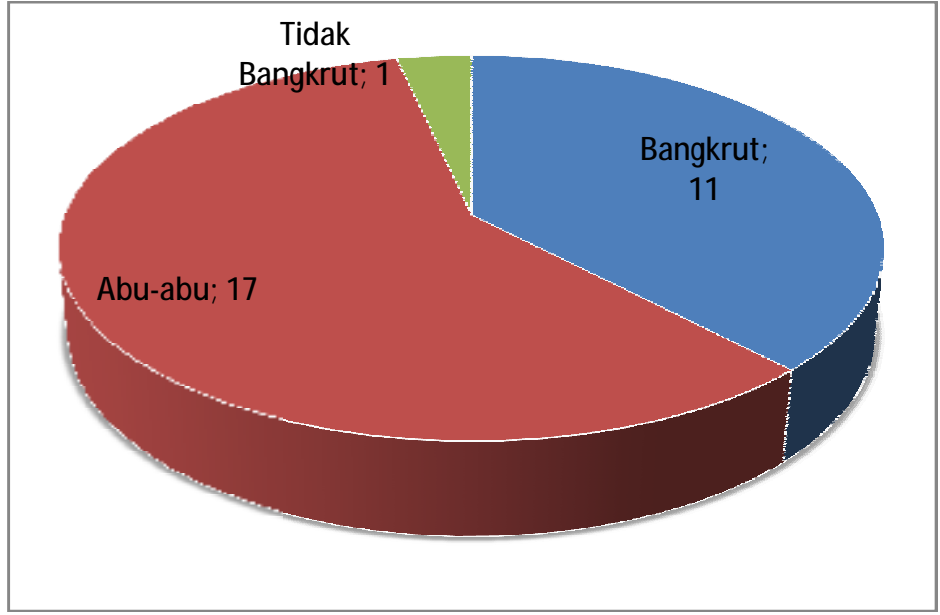

Gambar 2.Resiko Kebangkrutan (Altman Z Zcore)Perbankan Tahun 2010 
Berdasarkan gambar 2 dapat dijelaskan bahwa terdapat 11 perusahaan yang mempunyai resiko kebangkrutan dalam kategori "bangkrut", 17 perbankan yang masuk kategori "Abu-abu" dan 1 perbankan yang termasuk dalam kategori "tidak bangkrut". Dalam pendekatan Altman Z Score ini nilai pasar terhadap ekuitas mempunyai peran penting dalam mendongkrak nilai diskriminannya.

b. Altman Z Score Tahun 2011

Selanjutnya akan dilakukan analisis data lanjutan yaitu pada tahun 2011. Dengan pendekatan yang sama, maka akan dihasilkan hasil penelitian sebagai berikut:

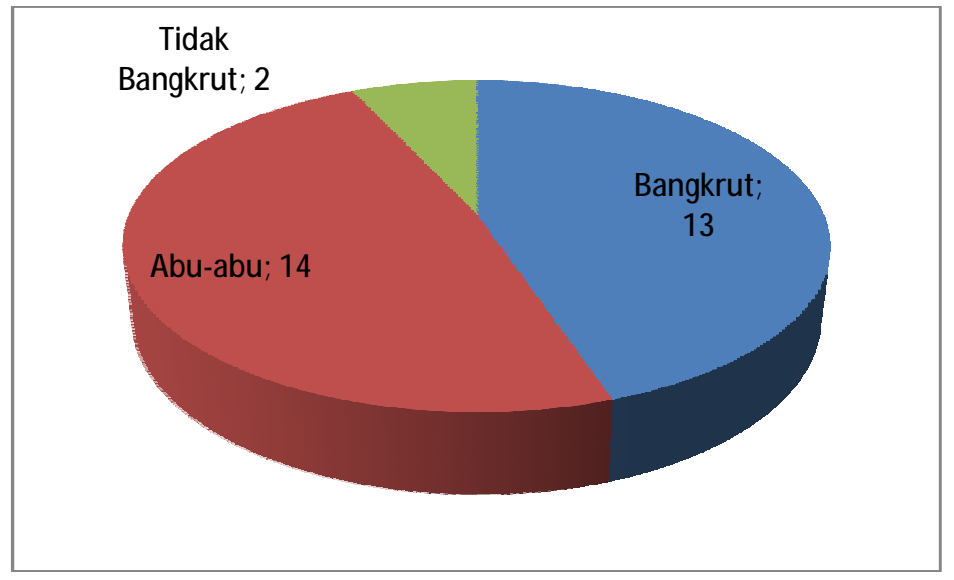

Gambar 3. Resiko Kebangkrutan (Altman Z Zcore) Perbankan Tahun 2011

Berdasarkan data pada gambar gambar3 dapat dijelaskan bahwa perbangkan yang mempunyai resiko kebangkrutan pada kategori "bangkrut" sebanyak 13, kategori "abu-abu" 14, dan yang mempunyai resiko kebangkrutan kategori "tidak bangkrut" sebanyak 2 perusahaan.

c. Altman Z Score Tahun 2012

Berikut merupakan hasil perhitungan untuk menilai resiko kebangkrutan dengan menggunakan pendekatan Altman Z score nonmanufaktur.

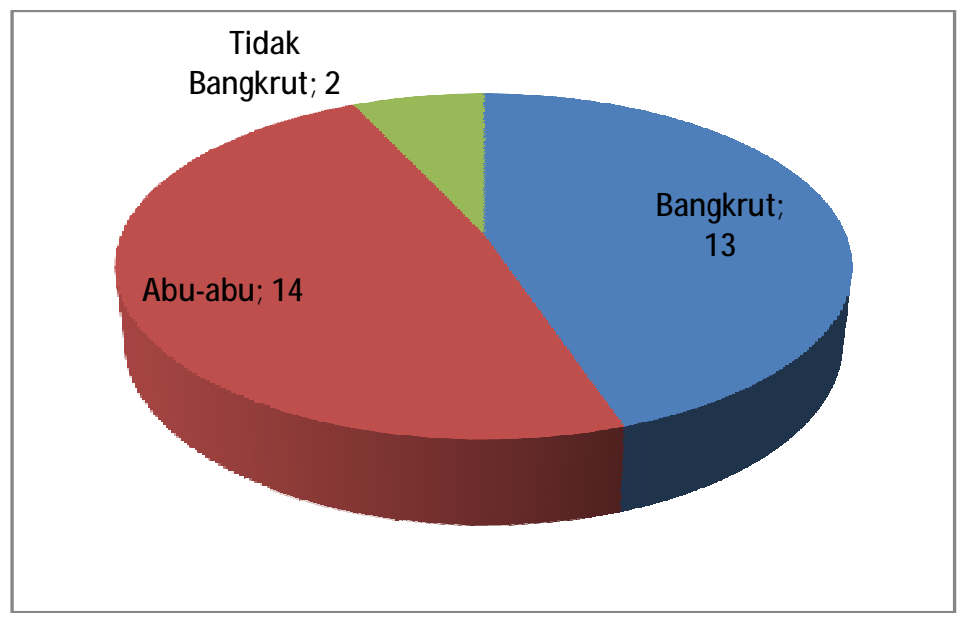

Gambar 4. Resiko Kebangkrutan (Altman Z Zcore) Perbankan Tahun 2012 
Berdasarkan data pada gambar gambar 4 dapat dijelaskan bahwa perbangkan yang mempunyai resiko kebangkrutan pada kategori "bangkrut" sebanyak 13, kategori "abu-abu" 14, dan yang mempunyai resiko kebang krutan kategori "tidak bangkrut" sebanyak 2 perusahaan.

d. Altman Z Score Tahun 2013

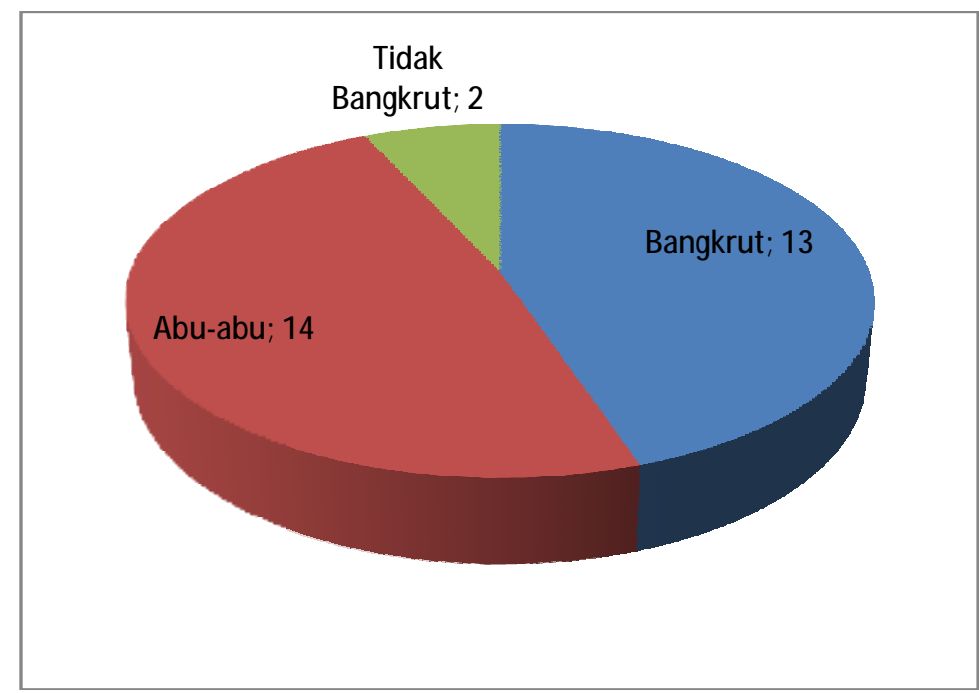

\section{Gambar 5. Resiko Kebangkrutan (Altman Z Zcore) Perbankan Tahun 2013}

Berdasarkan data pada gambar 5 dapat dijelaskan bahwa perbangkan yang mempunyai resiko kebangkrutan pada kategori "bangkrut" sebanyak 13 , kategori "abu-abu" 14, dan yang mempunyai resiko kebangkrutan kategori "tidak bangkrut" sebanyak 2 perusahaan.

e. Altman Z Score Tahun 2014

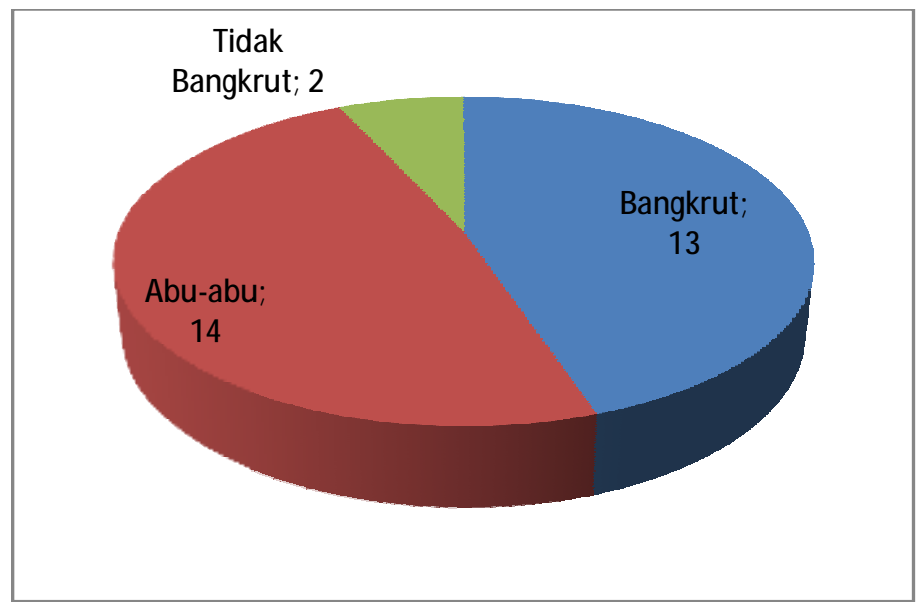

Gambar 6. Resiko Kebangkrutan (Altman Z Zcore) Perbankan Tahun 2014

Berdasarkan data pada gambar 6 dapat dijelaskan bahwa perbangkan yang mempunyai resiko kebangkrutan pada kategori "bangkrut" sebanyak 13, 
kategori "abu-abu" 14, dan yang mempunyai resiko kebangkrutan kategori "tidak bangkrut" sebanyak 2 perusahaan.

\section{Analisis Intel lectual Capital}

Berdasarkan alasan tersebut maka pada penelitian ini akan melakukan analisis data dengan menggunakan metode Value Added Intellectual Capital (VAICTM) untuk mengetahui performa perusahaan dilihat dari perspektif Intellectual Capital. Adapun penjelasannya adalah sebagai berikut:

a. Intellectual Capital 2010

Terdapat beberapa variabel penting yang digunakan untuk menghitung nilai VAIC yaitu input dan output perusahaan, beban biaya karyawan dan equity. Berdasarkan angka-angka tersebut maka dapat dilakukan pershitungan sebagai berikut:

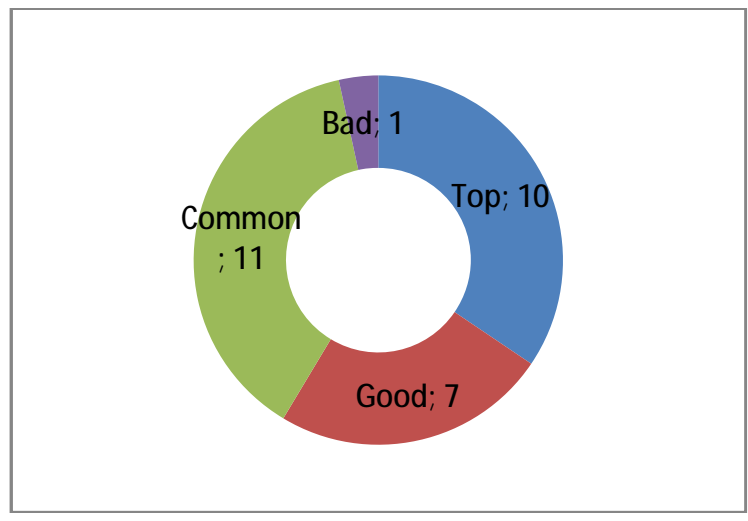

\section{Gambar 7. Performa Perbankan Dilihat dari Intellectual Capitalnya}

Berdasarkan tampilan data pada gambar 7 dapat dijelaskan bahwa perusahaan yang memiliki top performers sebanyak 10 perusahaan, good performers sebanyak 7 perusahaan, common performers sebanyak 11 perusahaan, dan bad performers sebanyak 1 perusahaan. Dengan demikian sebagian besar perbankan yang ada di Indonesia ini performa dari perspektif intellectual capitalnya masih dikatakan baik, hal ini dikarenakan sebagian besar masuk dalam kategori top dan good performers.

b. Intellectual Capital 2011

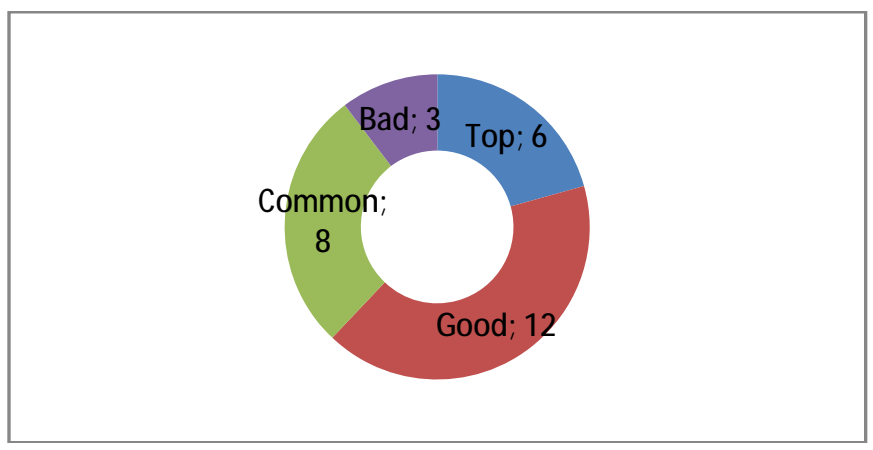

\section{Gambar 8. Performa Perbankan Dilihat dari Intellectual Capitalnya}

Berdasarkan tampilan data pada gambar 8 dapat dijelaskan bahwa perusahaan yang memiliki top performers sebanyak 10 perusahaan, good performers sebanyak 7 perusahaan, common performers sebanyak 11 
perusahaan, dan bad performers sebanyak 1 perusahaan. Dengan demikian sebagian besar perbankan yang ada di Indonesia ini performa dari perspektif intellectual capitalnya masih dikatakan baik, hal ini dikarenakan sebagian besar masuk dalam kategori top dan good performers.

c. Intellectual Capital 2012

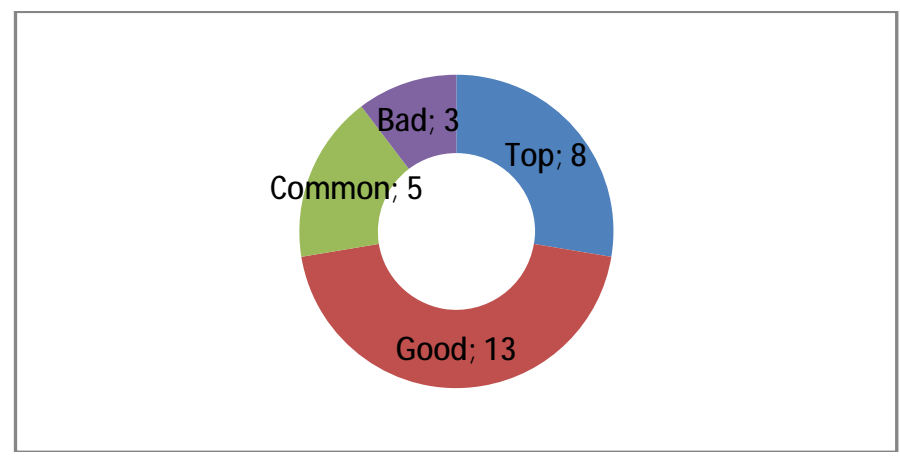

\section{Gambar 9. Performa Perbankan Dilihat dari Intellectual Capitalnya}

Berdasarkan tampilan data pada gambar 9 dapat dijelaskan bahwa perusahaan yang memiliki top performers sebanyak 8 perusahaan, good performers sebanyak 13 perusahaan, common performers sebanyak 5 perusahaan, dan bad performers sebanyak 3 perusahaan. Dengan demikian sebagian besar perbankan yang ada di Indonesia ini performa dari perspektif intellectual capitalnya masih dikatakan baik, hal ini dikarenakan sebagian besar masuk dalam kategori top dan good performers.

d. Intellectual Capital 2013

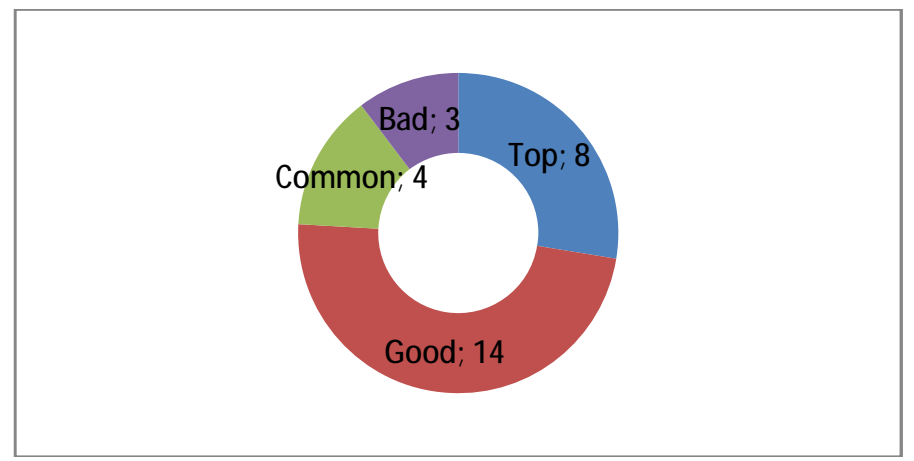

\section{Gambar 10. Performa Perbankan Dilihat dari Intellectual Capitalnya}

Berdasarkan tampilan data pada gambar 10 dapat dijelaskan bahwa perusahaan yang memiliki top performers sebanyak 8 perusahaan, good performers sebanyak 14 perusahaan, common performers sebanyak 4 perusahaan, dan bad performers sebanyak 3 perusahaan. Dengan demikian sebagian besar perbankan yang ada di Indonesia ini performa dari perspektif intellectual capitalnya masih dikatakan baik, hal ini dikarenakan sebagian besar masuk dalam kategori top dan good performers. 
e. Intellectual Capital 2014

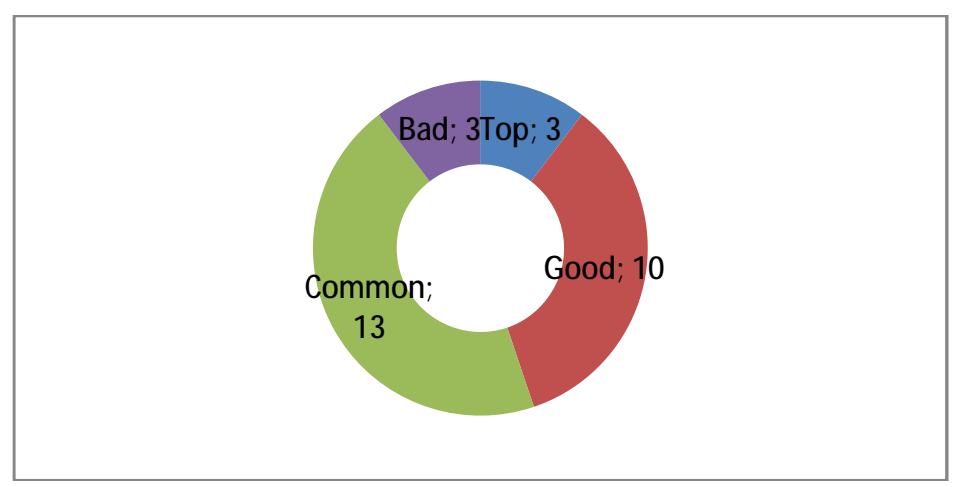

\section{Gambar 11. Performa Perbankan Dilihat dari Intellectual Capitalnya}

Berdasarkan tampilan data pada gambar 11 dapat dijelaskan bahwa perusahaan yang memiliki top performers sebanyak 3 perusahaan, good performers sebanyak 10 perusahaan, common performers sebanyak 13 perusahaan, dan bad performers sebanyak 3 perusahaan. Dengan demikian sebagian besar perbankan yang ada di Indonesia ini performa dari perspektif intellectual capitalnya masih dikatakan baik, hal ini dikarenakan sebagian besar masuk dalam kategori top dan good performers.

\section{Pengaruh Intellectual Capital pada Resiko Kebangkrutan}

Tabel 1 .Uji Hipotesis:Intellectual Capital Berpengaruh Terhadap Resiko Kebangkrutan

\begin{tabular}{|l|r|r|r|}
\hline \multirow{2}{*}{$\begin{array}{l}\text { Konstanta } \\
\text { Intel lectual Capital }\end{array}$} & \multicolumn{3}{|c|}{ Resiko Kebangkrutan } \\
\cline { 2 - 4 } & Koefisien & Nilai Uji t & \multicolumn{1}{c|}{ Sig } \\
\cline { 2 - 4 } & 2.658 & 18.682 & 0,000 \\
\hline F & $-0,127$ & -3.106 & 0,004 \\
Sig. & & & 9.645 \\
R & & & $0,004^{\mathrm{b}}$ \\
R2 & & & $0,513^{\mathrm{a}}$ \\
R2 adj & & & 0,263 \\
\hline
\end{tabular}

Sumber: Data Primer, 2015

Persamaan regresi pada hipotesis adalah:

\section{Resiko Kebangkrutan $=\mathbf{2 . 6 5 8}+(-0.127)$ Intel lectual Capital}

Hasil pengolahan data ini menunjukkan bahwa koefisien konstanta signifikan (2.658 dengan nilai uji $\mathrm{t}=18.682$ dan signifikansinya $0,000<0,05$. Koefisien variabel Intellectual capital signifikan (-0.127 dengan nilai uji $t=-3.106$ dan signifikansinya $0,004<0,05)$. Berdasarkan data tersebut dapat dikatakan bahwa intellectual capitalmemberikan pengaruh negatif terhadap resiko kebangkrutan. Hasil regresi di atas juga menunjukkan bahwa nilai $\mathrm{R} 2=0,263$. Hal ini berarti bahwa intellectual capital dapat dijelaskan oleh variabel resiko kebangkrutan sebesar $26,3 \%$, sedangkan sisanya $63,7 \%$ dijelaskan oleh variabel lain yang tidak diteliti pada penelitian ini. 
Berdasarkan keterangan di atas dapat dinyatakan bahwa intellectual capital berpengaruh negatif pada resiko kebangkrutan. Artinya semakin performa perusahaan tinggi dalam perspektif intellectual capital maka resiko kebangkrutan akan semakin kecil. Dengan demikian hipotesis pada penelitian ini terbukti.

\section{Pembahasan Hasil Penelitian}

1. Analisis Resiko Kebangkrutan dengan Menggunakan metode Altman Z score

Berdasarkan hasil penelitian di atas, maka dapat dibuat ringkasan hasil penelitian dari tahun 2010 sampai 2014 dalam penilaian resiko kebangkrutan dengan menggunakan Altman Z score. Pada perbankan di Indonesia yang go public, Working capital dalam hal ini didapat dari pengurangan current asset dengan current liability, mempunyai nilai yang kecil jika harus dibandingkan dengan total asset. Sehingga sumbangan nilai terhadap Z score relatif kecil.

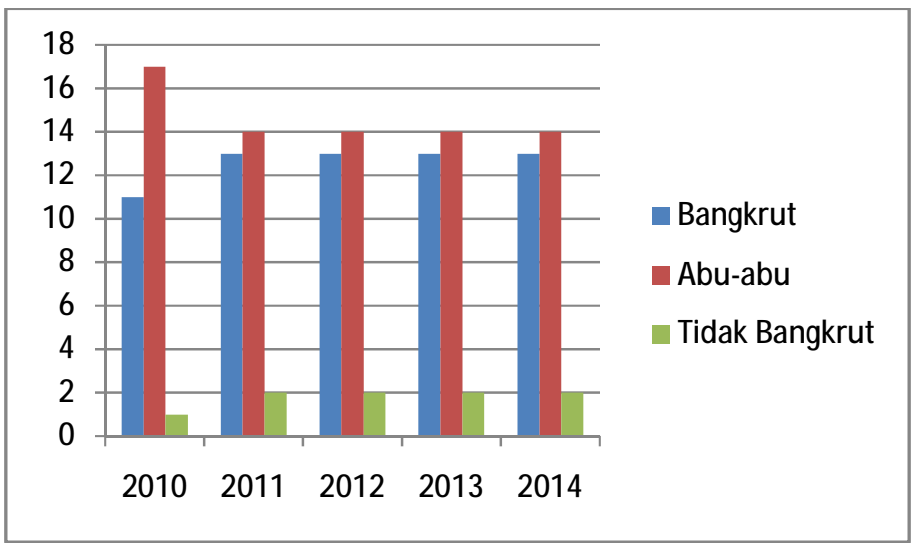

\section{Gambar 12. Grafik Altman Z Score dari tahun 2010 sampai 2014}

Berdasarkan gambar 12 dapat dijelaskan bahwa dari ketiga kategori penilaian resiko kebangkrutan pada tahun 2010 kategori "abu-abu" paling banyak, kemudian kategori "bangkrut" nomor dua, dan yang "tidak bangkrut" paling sedikit.terdapat beberapa indicator pada pendekatan Altman Z Score diantaranya total asset, working capital (current asset-current liabilities), EBIT, retained income, market value to equity dan total liabilitity. Jika dilihat dari indicator pendekatan Altman Z Score tersebut, rata-rata yang menyumbang nilai tinggi adalah $\mathrm{X} 4$ yang didalamnya terdapat indicator market value to equity dan total liabilities. Hal ini berbeda dengan hasil penelitian Pradhan (2014) yang dalam penemuannya menempatkan $X 1$ working capital dan total asset menyumbang nilai tinggi untuk menjadikan nilai Altman Z score perbankan mempuyai nilai tinggi atau masuk kategori "tidak bangkrut".

Penelitian mengenai Altman's Z-Score, Financial distress dan prediksikebangkrutan pernah digunakan oleh: Altman (1968) (dalam Esmeralda et.al,2004) melakukan penelitian menggunakan teknik multivariate discriminantanalysis dan menghasilkan model dengan 7 rasio keuangan. Dalam penelitiannya,Altman meng gunakan sampel 33 pasang perusahaan yang pailit dan tidak pailitdengan model yang disusunnya secara tepat mampu mengidentifikasikan 90persen kasus kepailitan pada satu tahun sebelum kepailitan terjadi. Ditambahkan Altman (1968) menyatakan bahwaperusahaan kesulitan keuangan umumnya mempunyai rasiolikuiditas, profitabilitas, dan aktivitas yang rendah. Indikatorkeuangan lain yang dipakai dalam prediksi adalah struktur pasaryang membandingkan nilai pasar ekuitas dengan nilai buku hutang.Likuiditas suatu perusahaan didefinisikan sebagai kemampuan 
perusahaanuntuk memenuhi semua kewajibannya yang sudah jatuh tempo, yaitu, apakahperusahaan memiliki sumber dana yang cukup untuk membayar kreditur saatkewajiban itu jatuh tempo. Rasio profitabilitas digunakan untuk mengetahuisecara relatif apakah laba yang dihasilkan perusahaan sudah cukup jikadibandingkan dengan aktiva yang diinvestasikan. Masalah pendanaan perusahaan,apakah menggunakan hutang atau ekuitas dapat dijawab dengan rasio hutang(debt ratio) yang membandingkan total hutang dengan total aset, rasio labaoperasi terhadap beban bunga (times interest earned ratio) yang membandingkanlaba operasi dengan bunga, serta rasio-rasio lain yang berhubungan dengankeputusan pendanaan. Rasio aktivitas digunakan untuk mengukur seberapa efektifperusahaan mengelola aktiva.

\section{Penilaian Performa Bank dari Perspektif Intel lectual Capital dengan Metode VAIC}

Setalah dilakukan analisis data maka dapat dilakukan pembahasan untuk mendapatkan interpretasi yang lebih mendalam terhadap hasil penelitian.

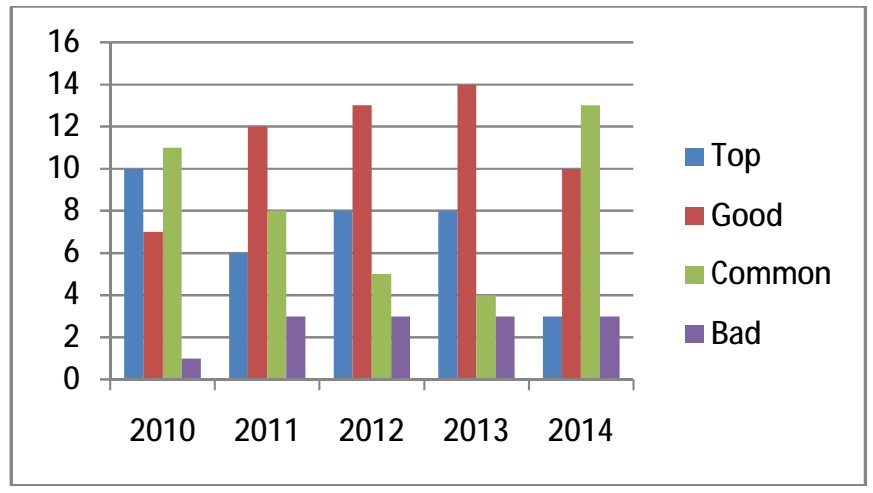

Gambar 1.12 Grafik Intellectual capital Metode VAIC Tahun 2010-2014

Ulum (2014) menjelaskan dalam penelitiannya bahwa dengan menggunakan metode VAIC didapatkan hasil top performersnya adalah BBCA, BBRI dan BMRI, dan PNBN. Demikian uga dengan hasil penelitian ini bahwa top performersnya antara lain BBCA, BMRI dan BBRI. Dengan demikian hasil penelitian ini sejalan dengan penelitiannya Ulum (2014).

Stewart (1997) dalam Rehman et al. (2011) mendefinisikan intellectual capital sebagai suatu pengetahuan dan informasi yang menciptakan efisiensi value added untuk menghasilkan kekayaan perusahaan. Pulic (2001) dalamRehman et al. (2011) menyimpulkan intellectual capital sebagai kemampuanpegawai untuk menciptakan efisiensi value added.

Di Indonesia sendiri, fenomena IC mulai berkembang terutama setelah munculnya PSAK NO 19 tentang aktiva tidak berwujud walaupun tidak dinyatakan secara eksplisit, dimana dalam Paragraph 09 disebutkan beberapa contoh dari aktiva tidak berwujud antara lain pengetahuan dan teknologi, desain dan implikasi sistem baru, lisensi, hak kekayaan intelektual, pengetahuan mengenai pasar dan merk dagang. Kenyataan bahwa tidak seperti akuntansi tradisional yang fokus pada kontrol biaya saja, namun akuntansi modern sekarang sudah harus memperhitungkan value creation sejalan dengan penelitian Pulic yang dikenal dengan VAICTM. 


\section{Pengaruh I ntel lectual Capital pada Resiko Kebangkrutan}

Menurut Altman (1968) dalam Altman (1982) Altman Z-score adalah suatu alat yang digunakan untuk meramalkan tingkat kebangkrutan suatu perusahaan dengan menghitung nilai dari beberapa rasio lalu kemudian dimasukan dalam suatu persamaan diskriminan. Altman Z-score ini ditemukan oleh Altman (1968), tujuan dari analisis ini adalah ramalan terhadap kebangkrutan digunakan sebagai suatu kasus yang membantu menjelaskan. Singkatnya, seperangkat rasio ekonomi dan keuangan akan diteliti dalam suatu konteks ramalan kebangkrutan dimana suatu metodologi statistik multidiskriminan digunakan.

Hasil penelitian ini menunjukkan adanya pengaruh negative yang signifikan antara intellectual capital pada resiko kebangkrutan. artinya jika intellectual capital semakin besar nilainya maka resiko kebangkrutan semakin rendah. Hal ini sesuai dengan penelitiannya Mollabashi (2014) yang mengatakan bahwa terdapat pengaruh negative yang signifikan antara intellectual capital terhadap resiko kebangkrutan.

Organisation for Economic Cooperation and Development (OECD, 1999 dalam Ulum, 2009) menjelaskan IC sebagai nilai ekonomi dari dua kategori aset tak berwujud yaitu organisational (structural) capital dan humancapital. Organisational (structural) mengacu pada hal seperti system software, jaringan distribusi, dan rantai pasokan. Human capital meliputi sumber daya manusia dalam organisasi dan sumber daya eksternal yang berkaitan dengan organisasi.

\section{SIMPULAN}

\section{Simpulan}

Berdasarkan hasil penelitian dan pembahasan, maka dapat ditarik beberapa kesimpulan sebagai berikut:

1. Selamatahun 2010 - 2014 rata-rata perbankan yang terindikasi bangkrut $43,45 \%$, abu-abu 50,34\%, dan tidak bangkrut 6,21\%.

2. Nilai rata-rata intellectual capital padatahun 2010-2014 dengan kategori top sebanyak $24,14 \%$, good sebanyak $38,62 \%$, common sebanyak $28,28 \%$ dan bad sebanyak $8,97 \%$. Dengan demikian dapat dikatakan bahwa intellectual capital perbankan di Indonesia relative baik untuk mendukung kinerja perusahaan.

3. Terdapat pengaruh negative yang signifikan antara intellectual capital terhadap resiko kebangkrutan.

\section{Keterbatasan}

Keterbatasan pada penelitian ini adalah sebagai berikut:

1. Penelitian ini hanya menggunakan dasar laporan keuangan sebagai dasar untuk melakukan penelitian.

2. Penelitian ini belum mengkaji detail tentang pengaruhnya disetiap indicator sehing ga hasilnya merupakan nilai akhir Altman Z score dan nilai VAIC.

\section{Saran}

Saran pada penelitian ini adalah sebagai berikut:

1. Berdasarkan hasil penelitian ini mengungkapkan perusahaan perbankan di Indonesia masuk kategori abu-abu atau grey area sehingga ini menjadi signal bagi perusahaan perbankan untuk dapat berhati-hati dalam menentukan kebijakan stratgeis ditengah ketidakpastian kondisi ekonomi global sekarang.

2. Kebangkrutan adalah peristiwa yang menyakitkan bagi perusahaan, kedepan peneliti selanjutnya sebaiknya terus mengembangkan penelitian yang mengkaji tentang resiko kebangkrutan agar dapat dijadikan acuan yang relevan bagi perusahaan untuk tetap survive dan tumbuh berkelanjutan. 


\section{DAFTAR PUSTAKA}

Agarwal, V. and Taffler, R.J. (2007), "Twenty-five years of the taffler Z score model: does it really have predictive ability?", Accounting \& Business Research, Vol. 37 No. 4, pp. 285-300.

Al-Musalli, M. A. K., \& Ismail, K. N. I. K. (2012). Corporate Governance, Bank Specific Characteristics, Banking Industry Characteristics, and Intellectual Capital (IC) Performance of Banks In Arab Gulf Cooperation Council (GCC) Countries. Asian Academy ofManagement Journal of Accounting and Finance, 8(Supp. 1), 115-135.

Altman, E.I. (2002), "Corporate distress prediction model in a turbulent economic and Basel II environment". Emerald Group Publishing Limited, Strategic \& Leadership,

Andriessen, D. (2004). Making sense of intellectual capital : designing a method for thevaluation of intangibles. Jordan Hill, Oxford, UK: Elsevier, Inc.

Basuki, \& Kusumawardhani, T. (2012). Intellectual Capital, Financial Profitability, and Productivity: An Exploratory Study of the Indonesian Pharmaceutical Industry. Asianjournal of Business and Accounting 5(2), 41-68.

Bellora, L., \& Guenther, T. W. (2013). Drivers of innovation capital disclosure in intellectual capital statements: Evidence from Europe. The British Accounting Review, 1-16.

Brinker, B. (1998). Intellectual capital: Tomorrow's asset, today's challenge. Retrieved 15 December, 2006, from http://www.cpavision.org/vision/wpaper05b.cfm

Brooking, A. (1996). Intellectual Capital: Core Assets for the Third Millennium. London: Enterprise Thomson Business Press.

Brigham, Eugene. Joel F.Houston. 2001. Manajemen Keuangan. Edisi kedelapan. Buku II. Jakarta: Erlangga.

Calandro, J. (2007), "Considering the utility of Altman's Z score as a strategic assessment and performance management tool", Emerald Group Publishing Limited, Strategic \& Leadership, Vol. 35 No. 5, pp. 37-43.

Jayadev, M. (2006), "Predictive power of financial risk factors: an empirical analysis of default companies", The Journal for Decision Makers, Vol. 31 No. 3, pp. 45-56.

Kasmir. 2008. Bank dan Lembaga Keuangan Lainnya. Edisi Revisi. Jakarta: PT. Raja Grafindo Persada.

Kamal, M. H. M., Mat, R. C., Rahim, N. A., Husin, N., \& Ismail, I. (2011). Intellectual Capital and Firm Performance of Commercial Banks In Malaysia. Asian Economic andFinancial Review, 2(4), 577-590.

Kamath, G. B. (2007). The intellectual capital performance of Indian banking sector. Journa of Intellectual Capital, 8(1), 96-123. http://dx.doi.org/10.1108/14691930710715088

Khanqah, V. T., Khosroshahi, M. A., \& Ghanavati, E. (2012). An Empirical Investigation of the Impact of Intellectual Capital on Firms ' Market Value and Financial Performance: Evidence from Iranian Companies. International Journal of Management Business Research,2(1), 1-12.

Liu, Y., Papakirykos, E. and Yuan, M.W. (2004), "Market valuation and risk assessment of canadians banks", Bank of Canada, Working Paper No. 34, September.

Parashar, S.P. (2000), "Z score of UAE companies", Emirates Institute for Banking and Financial Studies, Research Paper, November..

Sauer, T.G. (2002), "How may we predict bankruptcy?", CCE, Business Credit Selected Topic, September, pp. 16-17.

Sugiyono. 2011. Metode Penelitian Kuantitatif, Kualitatif dan R\&D. Bandung: Alfabeta.

Vogel, F.E. and Hayes, S.L. III (1998), Islamic Law and Finance, Religion, Risk, and Return, Kluwer Law International, The Hague, pp. 2-3.

Zhang, L., Chen, S., Yen, J. and Altman, E.I. (2006), "Corporate financial distress diagnosis in China". 
Jurnal Bisnis \& M anajemen

Vol. 17, N o. 1, $2017: 25$ - 40 